GLOBAL JOURNAL OF EDUCATIONAL RESEARCH VOL 17, 2018: 61-71

COPYRIGHT@ BACHUDO SCIENCE CO. LTD PRINTED IN NIGERIA. ISSN 1596-6224

www.globaljournalseries.com; Info@globaljournalseries.com

\title{
CLASSROOM ENVIRONMENT AND ACADEMIC INTEREST AS CORRELATES OF ACHIEVEMENT IN SENIOR SECONDARY SCHOOL CHEMISTRY IN IBADAN SOUTH WEST LOCAL GOVERNMENT AREA, OYO STATE, NIGERIA
}

BONIFACE UGWUMADUKA EZIKE

(Received 1, February 2018; Revision Accepted 19, April 2018)

\begin{abstract}
This study investigated classroom environment and students' academic interest as correlates of achievement in Senior Secondary Chemistry.

Correlational design was adopted. 208 SS II students from ten randomly selected Public Secondary Schools in Ibadan Oyo State, Nigeria participated. Instruments include Classroom Environment Students' Questionnaire $(r=0.76)$, Students' Academic Interest Scale $(r=0.81)$ and Chemistry Achievement test $(r=0.85)$. Four null hypotheses were tested at.05 alpha level of significance. Pearson Product Moment Correlation and Multiple Regression Analysis were used for data analysis.

Result showed significant relationships between classroom environment and academic achievement, students' academic interest and achievement in Chemistry. Composite contribution of classroom environment and academic interest was significant. However, classroom environment better predicted achievement than students' academic interest.

Conclusion was that the predictor variables are active correlates of achievement in Chemistry. Therefore it was recommended that all hands should be on deck in providing conducive school and classroom environments for learning, teachers and parents should create activities that will help develop and sustain interest of students.
\end{abstract}

KEY WORDS: Classroom environment, Academic Interest, Achievement

WORD COUNT: 170

\section{INTRODUCTION}

Parents both educated and illiterates send their wards to school for a variety of reasons. These parents commit so much resources towards the education of these children at different levels. To whom much is given the adage says much is expected. This expectation from the parents is concretized in the form of academic achievement which comes in the form of results to parents. This becomes the yardstick with which academic success is measured or determined and this expectation becomes more worrisome when children's academic achievement is below expectation at the Secondary School level.

This is so because the Secondary School system in Nigeria is the link between the Primary School and tertiary institutions. It receives its population from the Primary school and prepares them for entry into the University. According to Suleman, Aslam and Hussain (2014) in determining the effectiveness of a national system of Education, Secondary education is

Boniface Ugwumaduka Ezike, Department of Educational Foundations and Instructional Technology, College of Specialized and Professional Education, Tai Solarin University of Education, ljagun, Ogun State, Nigeria.

(C) 2018 Bachudo Science Co. Ltd. This work is licensed under Creative Commons Attribution 4.0 International license. 
universally acknowledged as a fundamental stage. Since the quality of Higher Education depends upon the quality achieved at this level, many countries of the world focus their attention on exploring better solutions to the escalating and emerging problems encountered by adolescents at this level of education. It is therefore imperative to study academic achievement at the Secondary School and piece out factors affecting it. Academic achievement represents performance outcomes that indicate the extent to which a person has accomplished specific goals that were the focus of activities in instructional environments (Steinmay et al, 2014)) specifically in School, College and University. As the field of academic achievement depends on the indicators used to measure it, in this discourse, more curricular-based criteria such as grades or performance on an educational achievement test are the main focus. Because of the importance attached to achievement at the Secondary School level of Education, Suleman, Aslam and Hussain (2014), Kpolovie, Joe \& Okoto (2014) conclude that Secondary Education is the foundation stone for further studies and also for the development of a nation. This conclusion is very true of Nigeria where academic achievement in Secondary School Certificate Examination determines who proceeds to higher institutions. Many prospective graduands of Secondary Education have been frustrated out of further education for the simple reason of not being able to acquire the much needed grades to qualify them for the almighty Unified Tertiary Matriculation Examination,(UTME). One therefore begins to wonder why the desired optimum academic achievement has become very elusive.

This has led many educators and academic researchers to investigate into what has been responsible for this. Factors identified are indecisive with multiple variables. For instance Farooq, Chaudhry, Shafia \& Berhann (2011), Ezike and Bamiro (2015) found that socioeconomic status and parents' education have a significant effect on students' overall academic achievement. Others include study habit, attitude, self-efficacy, teacher quality, English Language proficiency, academic interest, personality factors, class attendance, age, learning styles, class size etc. Crosnoe, Johnson and Elder (2004) classified the factors of achievement into student factors, family factors, school factors and peer factors. Thinking along the line of this classification, this study is focusing on school and student factors but specifically on classroom environment and students' academic interest.

Nigeria, regarded as a third world nation is richly blessed with abundant and superb natural resources from the coastal States in the South to the fringes of the Northern Sahel States. This vast wealth has not translated into better life for the masses of Nigeria in all aspects including education. In Nigeria as the study was ongoing, recent development shows that most States are indebted to their teachers at both Secondary and Tertiary levels for at least six months. Some States have even resorted to payment of half salaries to their teachers. As a result of this, the Secondary Schools are now in total reckless abandon which on its own is a major factor prevailing against Secondary School academic achievement.

Every classroom plays host to different personality types of learners who come into the classroom differently prepared with a uniquely set characteristics that determine their levels of aspirations within the same classroom environment. The classroom environment is therefore a common playground hosting all these personalities at the same time. The problem of organizing these into a reasonable, identifiable and useful whole falls on the teacher who is the second living component in the classroom environment and a chief facilitator of learning. What features do the classroom possess which are able to synchronize the differences in individuals in the class to enable them benefit from the academic activities? The answer to this question can be found within the classroom environment. Classroom environment encompasses a broad range of educational concepts including the physical setting, the psychological environment created through social contexts and numerous instructional components related to the characteristics and behaviours (Miller \& Cunningham, nd).

Falsario, Muyong \& Neuvaespana (2014)) identified two aspects of classroom namely physical and social environment. According to them physical classroom environment refers to the arrangement of chairs, tables, fixtures and pieces of furniture, painting, lighting and ventilation while the social environment refers to the leadership exhibited by the teacher and the mode of students' participation and interaction. Suleman et al (2014) citing Fisher (2008) refers to physical environment as the physical room in which the 
teacher and the learners are the main elements including its spatial elements like the floor, windows, walls as well as other classroom equipments. According to them physical environment can affect students' comfort and also their ability to learn. Students who are comfortable are likely to get much information compared to those who are uncomfortable. Unfavourable classroom can discourage the learners and they become less willing to learn invariably affecting their interest in the whole academic process and space.

Classroom environment provides students' with effective instruction and promotes smooth teaching-learning process and affect academic achievement positively. The power of the classroom environment is expressed in the formulation of situational interest as key factor in the enhancement of student engagement. According to Kpolovie, Joe and Okoto (2014), situational interest is the affective reaction triggered by specific or appealing stimuli in the environment. It can be enhanced through the manipulation or modification of certain aspects of the learning environment and contextual factors such as teaching strategies, task presentation and structuring of learning experiences.

Mushtaq \& Khan (2012) identified internal and external classroom factors as factors strongly affecting students' academic performance. The internal factors among others include class schedules, class size, textbooks, test results, learning facilities, teacher's role, environment of the class etc. Interpreting the findings of Taylor \& Vlastos (2009 in Falsario et al 2014), Falsario et al (2014) wrote that classroom environmental design can facilitate and improve the learning process like the overt curriculum. It is unfortunate that in Nigeria, the situation is not much different as what obtains in Pakistan as reported in Falsario et al (2014)and in Kenya (Sang, 2013). The classrooms are overcrowded, inadequate facilities, lack of qualified teachers, lack of chairs and benches and in some schools students sit on windows while the teacher barely have enough space to move about. In some schools roof tops have been blown off by rain storms and the government practically feels unconcerned. In this type of scenario, there is nothing attractive to lure the students to the school and they prefer to play away their time rather than coming into dilapidating classrooms. Classrooms have collapsed killing learners in the process in some schools. Some empirical studies such as those of
Suleman et al (2014), Ekpo, Akpan, Essien \& Imo-obot (2009) found that classroom favourable environment has a significant positive effect on the academic achievement scores of Secondary School students.

Sang (2013) working with pre-school children in Uasin Gishu County, Kenya found that preschool children with favourable classroom environment had better performance in Mathematics when compared to preschools with unfavourable classroom. However the findings of Arul-Lawrence \& Vimala (2012) showed that there was no significant relationship between school environment which includes the classroom and academic achievement. Falsario et al (2014), in their study using two groups of students (Bachelor of Elementary Education (BEED) and Bachelor of Secondary Education, BSED) found that classroom climate could not influence academic performance of BEED students but for the BSED students there was a moderately low positive correlation between their academic achievement and classroom climate.

As noted earlier, unfavourable classroom environment can discourage learners and they become less willing to learn invariably affecting their interest in classroom activities. Interest as a psychological construct plays a major role in various life activities including academic. The decision to engage or not to engage in an activity, desire to persist or even to re-engage after disengagement and the degree of effort and time put into an activity are mainly dictated by the level of interest in the individual. This agrees with Frick's (1992) argument that interest influences what people attend to, think about, discuss and learn more about. In an academic activity, interest is a driving force behind students' participation. In this light, interest is referred to as an intrinsic motivation, that is, when individuals are intrinsically motivated, they engage in activities for their own sake and out of interest in the activity (Wigfield et al, 1998 in Goulart \& Bedi, 2011). This implies that there would be no need for a teacher to force or compel learners into engaging in an activity and participation therefore becomes a natural thing for the learners because right within them there is a self conviction to engage. Geiger and Cooper (1995) in Lawanto, Santoso \& Liu (2012) added the extrinsic goal orientation aspect of motivation that lead individual not only to participate in a task but also to evaluate how interesting, important and useful the task is. 
One common challenge facing teachers is how to introduce and teach in a manner that would generate interest in their students. Dewey much earlier in 1913 argued that if interest can be secured in a given set of facts or ideas, it will be perfectly sure that the pupils will direct their attention or energies towards mastering them. He further claimed that a strong interest will sustain an individual's attention and lead to sustained effort in accomplishing an academic goal. Hence, Renninger and Hidi (2002) in Kpolovie et al (2014) defined interest as a psychological state of having an affective reaction to and focus attention for particular content and or the relatively enduring predisposition to engage repeatedly in particular classes of objects, events or ideas. According to Adeyemi and Adeyemi (2014) interest has to do with a learner's predisposition to react positively in certain ways towards certain aspects of the environment and is usually developed in relation to and remains allied to more basic motives.

Kpolovie et al (2014) reported that situational interest which could be generated by the classroom environment is a potent medium that can be harnessed by teachers to motivate students' interest in learning even by the disengaged and unmotivated students to more effectively learn for probable better performance. Eberly Centre (2014) saddled with teaching excellence and educational motivation wrote that regardless of the objective value of an activity or topic, if students do not recognize its value, they may not be motivated to expend effort. However, if students clearly see how course work connects to their goals, interest and concerns, they will be more likely to value it and thus, more motivated to invest time and effort. To achieve this, the Centre proposed seven strategies which if adopted by the teacher might capture and sustain students' interest in any given class activity and lead to excellent achievement. The strategies are:

1. Clearly articulate learning goals,

2. Show relevance to students' academic lives,

3. Demonstrate relevance to students' professional lives,

4. Highlight real-world applications of knowledge and skills,

5. Connects to students' personal interest,

6. Allow students' some degree of choice and

7. Show your own passion and enthusiasm.

Lack of interest in a subject discourages students from staying in class and working hard to achieve a good grade and prevents them from being enthusiastic and taking the class seriously. Adeyemi and Adeyemi (2014) noted that when students lose interest in their studies, failure rate will be higher. Adding anti-social dimension to it, they wrote that students may engage in very many unlawful activities like cultism, robbery, prostitution and tyranny among other vices. Teachers are therefore enjoined to apply the suggested strategies in order to achieve the goal of generating interest in learners.

Relationship between interest and academic achievement has been studied empirically but according to Silvia (2006) in Kpolovie et al (2014), psychologists have characteristically disregarded close examination of interest as an overwhelming construct in the determination of human learning, motivation and emotion. This implies that much attention have not been paid to the effect of interest on students' academic achievement until very recently. All the same, Jayanthi, Balakrishnan, Ching, Abdullateef, and Nasirudeen (2014) working with 144 tertiary institution students in Singapore on factors contributing to academic performance found that among others, interest affected academic scores, Tella, Tella and Adeniyi (2011) working with 500 JSS students on locus of control, interest in schooling and self-efficacy as predictors of academic achievement in Osun State Nigeria, found that interest jointly and independently significantly predicted achievement, Lawanto, Santoso and Liu (2012) in their own work on understanding of the relationship between interest and expectancy for success in engineering design activity with grades 9-12 students found that there was a significant relationship between students' interest and expectancy for success. Also Kpolovie et al (2014) using a sample of 518 SSCE students in Port-Harcourt, Nigeria, worked on "Academic achievement Prediction: Role of interest in learning and attitude towards school". They found a significant correlation and multiple prediction of students' academic achievement with the explanation variables accounting for $21.60 \%$ of the variance in students' academic achievement. Also, Rotgans and Schmidt (2011), in their study with 69 Republic Polytechnic students, Singapore, in a one-day problem-based session, partly found that situational interest was highly predictive for observed classroom-related behaviours which in turn proved to be a significant predictor of academic achievement. 
On the contrary, some other researchers

have equally found that interest was not necessarily important in educational success. For example, Goulart and Bedi (2011) working on the impact of interest on educational success in Portugal, noted that after controlling for timeinvariant unobservable traits for the simultaneous determination of interest and achievement, there is little support for the idea that prior interest in school has a bearing on future educational success.

\section{Statement of the problem}

The prevalence of underachievement in most Secondary School subjects has dimmed the hopes and aspirations of many students in progressing into higher institutions. The direct fallout of this is dashing the great expectations of parents and other stakeholders in education. Accusing fingers have been pointed at the school system for being responsible while the school shifts the blame to the learners, government and parents. Literature reviewed in this study implicated so many other factors beyond the ones identified above. In a country where the annual budgetary allocation for education is abysmally low (UNESCO bench mark 26\%)with the leaders displaying a gross nonchalant attitude, the state of our schools especially the public Secondary Schools is in total shambles. The classrooms are in a terrible deplorable conditions precipitating and provoking an acrid apathy among students and their teachers leading to truancy on the part of the learners and skipping of classes by the teachers. This identified state of disrepair in the school environment and waning interest in the learners make this study imperative at this time of severe belt-tightening occasioned by nose-diving economy in Nigeria.

\section{Purpose of the Study}

The main purpose of this study is to investigate the predictive powers of classroom environment and students' academic interest on Senior Secondary School students' academic achievement in Chemistry. Other specific objectives of the study are to:

- examine the relationship between classroom environment and academic achievement of students in Senior Secondary School Chemistry,

- examine the relationship between academic interest and academic achievement of students in Senior Secondary School Chemistry,

- examine the joint contribution of classroom environment and academic interest to academic achievement of students in Chemistry and

- examine the relative contributions of classroom environment and academic interest to academic achievement of students in Chemistry.

\section{Research hypotheses}

The following null hypotheses were raised and tested at 0.05 alpha level of significance

$\mathbf{H}_{01}$ : There is no significant relationship between classroom environment and students' academic achievement in Senior Secondary School Chemistry.

$\mathbf{H}_{\mathrm{O} 2}$ : There is no significant relationship between students' academic interest and academic achievement in Senior Secondary School Chemistry.

$\mathbf{H}_{\mathrm{O} 3}$ : There is no significant composite contribution of classroom environment and academic interest to students' academic achievement in Senior Secondary School Chemistry.

$\mathbf{H}_{\text {04: }}$ There are no significant relative contributions of classroom environment and academic interest to students' academic achievement in Senior Secondary School Chemistry.

\section{Significance}

Environment is very important in the development of all living organisms be it home, school, workplace or even the market environment. In the school, environment determines whether a child will be happy and ready to learn or turn into a truant. Classroom environments are extremely important for both students and teachers. The physical, social and psychological or emotional environments must be such that every aspect of human behaviour is warmly accommodated. It is therefore important for teachers to understand this in order to understand how to organize their classrooms to create a better learning environment. This study will assist teachers to organize and control their classes in order to 
yield more positive consequences for their students than negative.

\section{METHODOLOGY}

Research design: The study adopted a descriptive survey research method with a correlational approach.

Target Population: The target population for this study was SS II Chemistry students in the twenty nine (29) Senior Secondary Schools in Ibadan South West Local Government Area of Oyo State, Nigeria.

Sample and Sampling Procedure: Two hundred and eight (208) Senior Secondary Two (SS II) students drawn from ten randomly selected Secondary Schools in Ibadan South West Local Government Area were used for the study. SS II students were selected because of the level of academic knowledge area covered and also were not being prepared for any immediate external examination.

Instruments: Three instruments were used. They are: Classroom Environment Students' Questionnaire (CESQ), Students' Academic Interest Scale (SAIS) and Chemistry Achievement Test (CAT).

$\begin{array}{llr}\begin{array}{l}\text { Classroom } \\ \text { Questionnaire }\end{array} & \text { Environment } & \text { Students' } \\ \text { The Classroom } & \text { Environment } & \text { Students' }\end{array}$
Questionnaire is an adapted participantcompleted questionnaire developed by Kelly (2010) and used for the collection of data for his doctoral theses in Australia. The earlier validations notwithstanding, the CESQ was slightly modified in terms of language use, sentence structure and vocabulary to reflect the local academic environment and culture of the Nigerian educational system. Also items that repeated themselves were deleted and as all items were positively stated; twenty items were reversed to negative items. This reversal was taken into consideration while scoring. Items 8 \& 9 in the original instrument evoked the same response and item 9 was deleted. The CESQ has two sections $A$ and $B$. Section $A$ deals with the biodata of the respondents while section $B$ contains the 49 item statements arranged on a four-point adapted Likert scale type of SA, A, D and SD. The re-validated CESQ was then administered to a parallel sample of a school that was not part of the study sample. Data generated were used for the calculation of reliability using Cronbach alpha and the coefficient obtained was 0.76 .

Students' Academic Interest Scale (SAIS): The Students' Academic Interest Scale is adapted from the Academic Interest Scale, a self-report 101-item inventory developed by Addison, Althoff \& Pezold (2009) and used by Althoff (2010). The scale consists of four subscales of motivation, organization, responsibility and self-awareness. The items used for the SAIS were generated from the original Academic Interest Scale. The SAIS consists of sections A and B. Section A deals with the biodata of the respondents while section B contains 30 item statements arranged on a four-point adapted Likert scale type of SA, $A, D$ and SD. The instrument was re-validated for local use and then administered to a parallel sample. Data collected were used for the calculation of reliability coefficient using Cronbach Alpha and the index obtained was 0.81 .

Chemistry Achievement Test (CAT): This instrument was developed by the researcher and was used for SSII Chemistry students. It consists of thirty items taken from the first term topics of SS II Scheme of work already treated by the entire population. The CAT is a multiple choice objective test with four options. For validation, the instrument was administered to a parallel sample of SS II Chemistry students who did not participate in the main study. The result of this administration was used to calculate the reliability using KR-20 and the index obtained was 0.85 .

\section{RESULTS}

$\mathbf{H}_{01}$ : There is no significant relationship between classroom environment and students' academic achievement in Senior Secondary School Chemistry.

This hypothesis was tested using Pearson Product Moment Correlation Coefficient and the result is presented in table 1. 
Table 1: Summary of Pearson Product Moment Correlation Coefficient showing relationship between classroom environment and students' academic achievement in Senior Secondary School Chemistry.

\begin{tabular}{|c|c|c|c|c|c|c|}
\hline (2) & Number & Mean & Std dev. & $\mathbf{r}$ & Sig & Remark \\
\hline Classroom environment & 208 & 67.8 & 7.31 & & & \\
\hline Achievement in Chem & 208 & 8.10 & 2.96 & .191 & $.006 *$ & Significant \\
\hline
\end{tabular}

${ }^{*} \mathrm{P}<0.01$

Results of analysis presented in table 1 show that the correlation coefficient $(r)$ is significant at $P<$ $.05(r=.191, P<.05)$. This Implies that the null hypothesis of no significant relationship is rejected indicating a relationship between school environment and students' academic achievement in Senior Secondary School Chemistry.
$\mathbf{H}_{\mathrm{O} 2}$ : There is no significant relationship between students' academic interest and students' academic achievement in Senior Secondary School Chemistry. This hypothesis was tested with Pearson Product Moment Correlation Coefficient and the result is presented in table 2 .

Table 2: Summary of Pearson Product Moment Correlation Coefficient showing the relationship between students' academic interest and academic achievement in Senior Secondary School

Chemistry.

\begin{tabular}{|c|c|c|c|c|c|c|}
\hline Variable & Number & Mean & Std dev. & $\mathbf{r}$ & Sig & Remark \\
\hline Academic Interest & 208 & 1.37 & .483 & & & \\
\hline Achievement in Chem & 208 & 8.10 & 2.96 & .14 & $.037^{*}$ & Significan \\
\hline
\end{tabular}

Result of analysis shown in table 2 reveals that the correlation $(r)$ is significant at $P<.05(r=.144$, $P<.05)$. This implies that the null hypothesis of no significant relationship is rejected indicating a significant relationship between students' academic interest and academic achievement in Senior Secondary School Chemistry.
Hypothesis three $\left(\mathrm{H}_{\mathrm{O}}\right)$ : There is no significant composite contribution of classroom environment and academic interest to students' academic achievement in Senior Secondary School Chemistry.

This hypothesis was tested with Multiple Regression Analysis and the results are presented in the following tables. 
Table 3: Model summary of the $R, R$ square and adjusted $R$ square in the Multiple Regression Analysis.

\begin{tabular}{lcccr}
\hline Model & $\mathrm{R}$ & $\mathrm{R}$ square & Adjusted & SE of the \\
$\mathrm{R}$ square & Estimate & & & \\
1 & $.241^{\mathrm{a}}$ & .058 & .049 & 2.88
\end{tabular}

a. predictors: (constant), classroom environment and academic interest

From table 3 , the $R^{2}$ is .058 , which indicates that 5.8 percent of the variance in the dependent variable is explained by the independent variables. This means that classroom environment and academic interest influenced academic achievement to the extent of $5.8 \%$. The remaining unexplained $94.2 \%$ may be as a result of several other variables not covered by this study.

Table 4: ANOVA summary of significance level in the multiple regression analysis

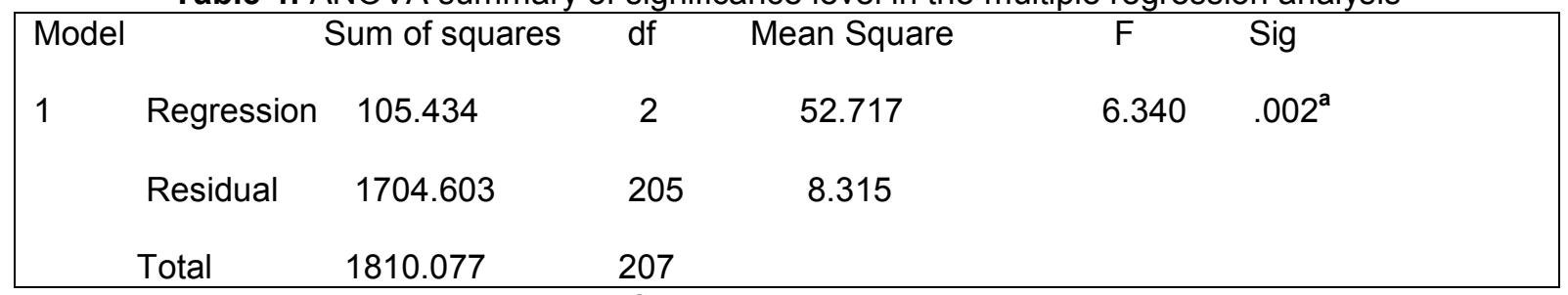

a. predictors: (constant), Classroom environment and Academic Interest.

Though the $R^{2}$ is low (Table 3 ), the Analysis of Variance is very significant $\left(0.002, \mathrm{~F}_{(2,207)}=\right.$ $6.340<0.05)$. This further indicates that there is a statistically significant relationship between the independent variables (classroom environment and academic interest) and the dependent variable (academic achievement in Chemistry) and that their composite contribution is significant. Therefore it can be assumed that the independent variables could reasonably predict academic achievement in Senior Secondary School Chemistry.

Hypothesis four $\left(\mathrm{H}_{\mathrm{O}}\right)$ : There are no significant relative contributions of classroom environment and academic interestto students' academic achievement in Senior Secondary School Chemistry. 
Table 5: The beta $(\beta)$ coefficients in the Multiple Regression Analysis showing the relative contributions of classroom environment and academic interest to students' academic achievement in Senior Secondary School Chemistry.

\begin{tabular}{|c|c|c|c|c|c|c|}
\hline \multicolumn{7}{|c|}{ Coefficients $^{a}$} \\
\hline \multirow[b]{2}{*}{ Model } & & \multicolumn{2}{|c|}{ Unstandardized coefficients } & \multicolumn{3}{|c|}{ Standardized coefficients } \\
\hline & & B & SE & Beta & $\mathbf{t}$ & Sig \\
\hline 1 & (Constant) & 1.563 & 1.961 & & .797 & .426 \\
\hline & CIrm environment & .078 & .027 & .193 & 2.852 & .005 \\
\hline & Academic Interest & .903 & .415 & 147 & 2.175 & .031 \\
\hline
\end{tabular}

a. Dependent Variable: Achievement levels

From table 5; the Beta $(\beta)$ weightings of the two predictor variables are given in the standardized coefficient column. The constant is 1.563 . Relative to each other, classroom environment has a positive effect on academic achievement $(\beta=.193)$ and this is statistically significant at (0.005, $P<0.05)$, students' academic interest has a positive effect on level of academic achievement $(\beta=.147)$ and this is statistically significant at $(.031, \mathrm{P}<0.05)$. From the result presented, it can be concluded that classroom environment had a statistically significant effect on academic achievement of students in Senior Secondary School Chemistry while academic interest had a positive contribution which was also statistically significant. Their different beta values represent their relative contributions to academic achievement. Classroom environment made a contribution of $19.3 \%$ while students' academic interest made a contribution of $14.7 \%$. Therefore, classroom environment predicts academic achievement in Senior Secondary School Chemistry more than students' Academic Interest.

\section{DISCUSSION}

This study was embarked on to seek if a relationship exists between the two independent variables (classroom environment and academic interest) and the dependent variables (academic achievement in Chemistry) and also to determine the contributions if any of the independent variables both jointly and independently (relatively) to academic achievement in Chemistry. Results show that there was a positive significant relationship between classroom environment and academic achievement. This finding is consonance with those of Taylor and Vlastos (2009) in Suleman and Hussain (2014) who wrote that classroom physical environment acts as a 'silent curriculum', Ekpo et al (2009) found that classroom climate had a significant relationship with academic achievement in Social Studies, Sang (2013) working with preschool children in Uasin Gishu county Kenya found that preschool children in favourable classroom environment had better performance in Mathematics (with a mean score 94.85) than their counterparts in unfavourable classroom environment (mean 48.03). Also Suleman et al (2014) in an experimental study with Senior Secondary students in Kohat Division, in Pakistan concluded that classroom favourable environment has a significant positive effect on the academic achievement scores of Senior Secondary students. The reason for this is that when a classroom environment is favourable, the students are comfortable and likely to get much information compared to those who are uncomfortable. When a classroom is well furnished with physical facilities coupled with an appealing social and psychological climate, learners become attracted to and interested in the activities going on in such a classroom environment. The result is however in dissonance with Arul-Lawrence and Vimala (2012) who found that there was no significant relationship between school environment and academic achievement of standard IX students and Falsario et al (2014) found that for a certain category of students (Bachelor of Elementary Education, BEED) there was a low positive correlation between classroom climate and academic performance. 
Result also showed that significant relationship exists between academic interest of students and achievement in Senior Secondary School Chemistry. This result is tenable because of the role interest plays in various life activities including academics. It is a wellknown/established fact that the decision to exert extra effort or even to engage in an activity is dictated by the level or degree of interest in an individual. This agrees with Frick's (1992) submission that interest influences what people attend to, think about, discuss and learn more about. The outcome of this study is in harmony with the empirical findings of Tella et al (2011), Lawanto et al (2012), Sang (2013), Kpolovie et al (2014) and Jayanthi et al (2014). However, some empirical findings such as Goulart and Bedi (2011) are at dissonance with this result.

This study equally found that the combination of classroom environment and academic interest of students predicted achievement in Senior Secondary School Chemistry. This is so because unfavourable classroom environment can discourage learners and they become less willing to learn invariably affecting their interest in classroom activities. As a corollary, it follows that classroom environment when favourably linked with interest will predict achievement in all subjects not only in Chemistry. This accounts for the result obtained when the independent variables were compositely yoked.

\section{CONCLUSION}

From the result of the study, it could be concluded that classroom environment is a vital factor that can affect academic achievement of learners. It has the potential to dictate the level of interest, motivation and subsequent commitment in any activity. Students' academic interest is also crucial since it was found to have positively affected achievement in Chemistry.

\section{RECOMMENDATION}

It is therefore recommended that all hands should be on deck in providing a conducive and vibrant school and classroom environments for the students. Towards this direction, governments at all levels should make funds available for this purpose and ensure that befitting classrooms, laboratories and workshops are constructed. Since the success of the students is linked with the students' homes, parents and teachers should create activities that will help to develop and sustain the interest of students.

\section{REFERENCE}

Adeyemi, A. M and Adeyemi, S. B., 2014. Institutional factors as predictors of students' academic achievement in Colleges of Education in South Western Nigeria. International Journal of Educational Administration and Policy Studies. 6(8), 141-153. http://www.academicjournals.org//JEAP S Retrieved 21/06/2016.

Addison, W. E., Althoff, R. W and Pezold, R., 2009. Academic maturity, critical thinking and academic performance in College students. Presented at the annual meeting of the American Psychological Association, Toronto.

Arul-Lawrence, A. S and Vimala, A., 2012. School environment and academic achievement of standard IX students. Journal of Educational and Instructional Studies in the World. 2(3), 210-215.

Althoff, R. W., 2010. The big five personality traits as predictors of academic maturity, unpublished Master's Thesis Eastern Illinois University U.S.A. $\mathrm{http} / / \mathrm{www}$.eiu.edu/graduate/forms/thesis Reproductioncert.html

Crosnoe, R., Johnson, M. K and Elder, G. H., 2004. School size and the interpersonal side of education: An examination of race/ethnicity and organizational context. Social Science Quarterly, 85(5), 1259-1274.

Eberly Centre., 2014. Explore potential strategies: Teaching excellence and educational innovation. Students lack interest or motivation. Carnegie Mellon University.http://www.cmu.edu/teaching/ solveproblem/stratlackmotivation/lackmotivation-01.html Ret. 21/06/2016,12.36pm

Ekpo, K., Akpan, O. E., Essien, E. E and ImoObot, M. M., 2009. Classroom climate and students' academic achievement Social Studies Cross River, Nigeria. African 
Research Review: An International Multi-Disciplinary Journal, Ethiopia. 3(4), 413-428 www.ajol.info

Falsario, H. N., Muyong, R. F and Nuevaespang, J. S., 2014. Classroom climate and academic performance of education students. Research report presented at DLSU Research Congress De La Salle University, Manilla, Philippines, March 6-8.

Frick, R. W., 1992. Interestingness. British Journal of Psychology, 83, 113-128.

Goulart, P and Bedi, A. S., 2011. The impact of interest in school on educational success in Portugal. Discussion Paper No 5462, Institute for the Study of Labour (IZA) Bonn in Association with University of Bonn.

Jayanthi, S. V., Balakrishnan, S., Ching, A. L. S., Abdul-Latiff, N. A and Nasirudeen, A. M. A., 2014. Factors contributing to academic performance of students in Tertiary Institutions in Singapore. African Journal of Educational Research 2 (9), 752-758

Kpolovie, P. J., Joe, A. I and Okoto, T., 2014. Academic achievement prediction: Role of interest in learning and attitude towards school. International Journal of Humanities, Social Science and Education.1(11), 73-100.

Lawanto, O., Santoso, H. B and Liu, Y., 2012. Understanding the relationship between interest and expectancy for success in engineering design activity in grades 912. Educational Technology and Society, $15 \quad$ (1), 152-161. http://www.ifets.info/journals/15-1/14.pdf Ret. 21/06/2016.

Mushtaq, I and Khan, S., 2012. Factors affecting students' academic performance. Global Journal of Management and Business Research.12(9), version 1.0.http://www. creativecommons.org/licenses/bync/3.01 Retrieved19/06/2016

Miller, A and Cunningham, K., (nd). Classroom environment: The Gale Group. Https// www.ortingscholls.org/cms/lib/WA01919 463/centricity/domain/326/purpose/rese arch/ClassroomArticle.pdfhttp://www.ed ucation.com/reference/article/classroom -environment/ Retrieved 23/06/2016

Paul Kelly., 2010. School and classroom environment of a small Catholic secondary school. Unpublished PhD Thesis, Australian Catholic University McAnley Campus, Virginia, QId 4014. Australia.

Rotgans, J. I and Schmidt, H. G., 2011. Situational interest and academic achievement in the active-learning classroom. Learning and Instruction 21 (1), 58-67. www.sciencedirect.com/science/article/p ii/s095947520900111X Ret. 25/05/2016.

Sang, C. J., 2013. Effect of classroom environment on academic performance mathematics of preschool children. In pioneer zone, Uasin Gishu County. Unpolished Med dissertation in Early Childhood Department of educational Communication and Technology, University Nairobi.

Steinmayer, R., Meibner, A., Weidinger, A. F and Wirthwein, L., (Undated). Academic achievement. DOI:10.1093/030/978019 975681-0108 www.oxfordbibliographies. com/view/document/0509780199756810/06097801997568100108.xml Retrieved 21/06/2016

Suleman, Q., Aslam, H. D and Hussain, I., 2014. Effect of classroom physical environment on the academic achievement scores of Senior Secondary students in Kohat Division, Pakistan. International Journal of Learning and Development. 4(1), 71-82. www.macrothink.org/ijld Retrieved 17/06/2016.

Tella, A., Tella, A and Adeniyi, S. O., 2011. Locus of control, interest in schooling and self efficacy as predictors of academic achievement among Junior Secondary Schools students in Osun State, Nigeria. New Horizon in Education, 59 (1), 25-37. 
